\title{
GEOCHEMICAL CHARACTERISTICS OF MICRODIAMONDS FROM KIMBERLITES AT LAC DE GRAS, CENTRAL SLAVE CRATON
}

\author{
Davies RM ${ }^{* 1,2}$, Griffin WL ${ }^{2,3}$, O'Reilly SY ${ }^{2}$, Doyle BJ ${ }^{4}$ \\ 1. American Museum of Natural History, New York, USA; ${ }^{2 .}$ GEMOC Macquarie University, Sydney, Australia; ${ }^{3 .}$ CSIRO \\ Exploration and Mining, North Ryde, Australia; ${ }^{4}$ Kenneott Canada Exploration Inc., Canada
}

Major and trace element compositions of mineral inclusions, carbon isotopes, nitrogen characteristics and morphologies of 549 microdiamonds from the DO27 (343) and seven other Lac de Gras (LDG) kimberlites (A154 (110), A418 (58), A21 (43), Ranch Lake (13), DO18 (6), DD17 (1)) in the central Slave Craton, Canada have been studied to elucidate the composition and geological history of the diamond bearing mantle beneath this craton and to compare micro- and macrodiamonds from the same kimberlite pipe (DO27; Davies et al., 1999).

\section{MINERAL INCLUSIONS}

The mineral inclusion study identified diamonds of the eclogitic $(62 \%)$, peridotitic $(25 \%)$ and ultradeep (13\%) parageneses.

\section{ECLOGITIC DIAMONDS}

Inclusions in eclogitic diamonds consist of Fe-sulfide, garnet, clinopyroxene, rutile and ilmenite in decreasing abundance. Thirty-six garnets recovered from 24 diamonds have variable $\mathrm{Ca}, \mathrm{Na}, \mathrm{Ti}$ and $\mathrm{Mg} \#$ (Gross $=14$ $54 \% ; \mathrm{Na}_{2} \mathrm{O}=0.13-0.26 \mathrm{wt} \% ; \mathrm{TiO}_{2}=0.36-1.2 \mathrm{wt} \% ; \mathrm{Mg} \#$ $=38-72$ ).

Clinopyroxene inclusions (35 from 30 diamonds) have omphacite and diopside compositions. In omphacite jadeite ranges from 9 to $39 \mathrm{~mol} . \%$ and potassium is in part high ( 0.04 to $1.6 \mathrm{wt} \% \mathrm{~K}_{2} \mathrm{O}$; av $\left.0.68 \mathrm{wt} \%\right)$. The higher potassium values are some of the highest recorded for clinopyroxene inclusions in diamond and are consistent with high-pressure crystallisation (Harlow and Veblen, 1991).

Diopside inclusions are typically large $(\leq 300 \mu \mathrm{m})$ and brown with amorphous textures. They occur enclosed in diamond often with other crystalline phases suggesting that they are syngenetic, however they may represent retrogressed products of former higher-pressure assemblages. Compositions are Ti-rich (0.16 to $1.27 \mathrm{wt} \%$ $\mathrm{TiO}_{2}$ ). One inclusion contains a zone of majorite with a compositionally calibrated pressure of formation in the order of $16 \mathrm{GPa}$ (Irifune, 1987).
Temperature estimates calculated for garnetclinopyroxene inclusions pairs in five diamonds range from 1040 to $1300{ }^{\circ} \mathrm{C}$ (av. $1190^{\circ} \mathrm{C}$ ) at a given pressure of $50 \mathrm{~Kb}$ (Ellis and Green, 1979). This places diamond formation close to the base of the lithosphere in this area (200-250 km; Griffin et al., 1999).

Fifty-six sulfide inclusions were extracted from 46 diamonds. Most inclusions are pyrrhotite, with nickel contents up to $7 \mathrm{wt} \%$. Ten of the sulfides occur in diamonds with clinopyroxene, garnet, $\mathrm{SiO}_{2}$, ilmenite or rutile. Rutile inclusions (9 diamonds) show $\mathrm{Fe}$ substituting for $\mathrm{Ti}(\leq 6.3 \mathrm{wt} \% \mathrm{FeO})$ and traces of $\mathrm{Al}$ and $\mathrm{Mg}$. One ilmenite inclusion is Fe-rich.

\section{Trace Elements}

Ten eclogitic garnet inclusions analysed for trace elements by LA-ICPMS are enriched in heavy rare earth elements (HREE) and depleted in light rare earth elements (LREE) $\left(\mathrm{La}_{\mathrm{N}} / \mathrm{Lu}_{\mathrm{N}}\right.$ ratios $\left.<1\right)$. Six eclogitic clinopyroxene inclusions show positive LREE slopes to $\mathrm{Nd}$ and shallow negative slopes from $\mathrm{Nd}$ to $\mathrm{Lu}$. The mean whole rock composition of a theoretical eclogite from which the DO27 and LDG diamonds could be derived has been calculated from an average trace element composition of the garnet and clinopyroxene inclusions assuming the modal composition of the eclogite represents a 1:1 mixture of garnet and clinopyroxene. The calculated bulk rock eclogite composition is similar to a typical midocean ridge basalt (NMORB).

\section{PERIDOTITIC DIAMONDS}

Peridotitic inclusions are mostly harzburgitic in composition and consist of olivine, sulfide, Cr-spinel, garnet, orthopyroxene and Cr-diopside. Olivine compositions from 14 diamonds are typical of diamond inclusions worldwide (Meyer, 1987; Fo 91.3 - 93.3, 0.33$0.41 \mathrm{wt} \% \mathrm{NiO}$ ) apart from two inclusions with high $\mathrm{Ca}$, $\mathrm{Mn}$ and low Ni contents ( $\sim 0.15 \mathrm{wt} \% \mathrm{CaO} ; 0.15-0.18 \mathrm{wt} \%$ $\mathrm{MnO} ; \quad 0.12 \mathrm{wt} \% \mathrm{NiO}$ ). These compositions are comparable to inclusions associated with lower mantle phases in diamonds (eg. Harte et al., 1999) originally 
having formed as spinel-structured $\left(\mathrm{Mg}, \mathrm{Fe}_{2}\right) \mathrm{SiO}_{4}$ at transition zone depths (ca 450-670 km).

Cr-pyrope garnet inclusions (4 diamonds) have high $\mathrm{Cr}$ contents and are subcalcic, indicating depleted harzburgitic compositions $\left(\mathrm{T}_{\mathrm{Ni}}=800-1040^{\circ} \mathrm{C}\right.$; Ryan et al., 1996). One inclusion with lower $\mathrm{Cr}$ and higher $\mathrm{Ca}$ is lherzolitic $\left(\mathrm{T}_{\mathrm{Ni}}=1300^{\circ} \mathrm{C}\right)$.

Cr-spinel inclusions (6 diamonds) have high $\mathrm{Cr} \#$ $((100 \mathrm{Cr} /(\mathrm{Cr}+\mathrm{Al}))$ av. 86$)$ and low $\mathrm{Mg} \#$ (av. 60) compared to other diamond inclusion data $(\mathrm{Cr} \#=75-90 ; \mathrm{Mg} \#=66$ av.; Griffin et al., 1991). One inclusion with low $\mathrm{Cr}$ and $\mathrm{Al}(\mathrm{Cr} \#=72)$, and high $\mathrm{Fe}$ and $\mathrm{Ti}$ is comparable to a suite of ultradeep diamonds from Brazil (Kaminsky et al., 2001).

Orthopyroxene (2 diamonds) and Cr-diopside (2 diamonds) have lherzolitic compositions. Peridotitic MSS sulfide inclusions from seven microdiamonds contain variable contents of $\mathrm{Ni}(8.7-60 \mathrm{wt} \%), \mathrm{Fe}, \mathrm{Co}$ (up to 14.7 wt $\%)$ and minor $\mathrm{Cu}$. Cobalt-rich sulfide inclusions (occurring in three DO27 diamonds) in diamond have not been reported previously.

\section{ULTRADEEP DIAMONDS}

Ultradeep diamonds host mineral inclusions of ferropericlase (18), $\mathrm{Mg}-\mathrm{Si}$ perovskite (3), $\mathrm{CaSiO}_{3}$ perovskite (2), $(\mathrm{Fe}, \mathrm{Mg})_{2} \mathrm{SiO}_{4}$ ?olivine (1) and $\mathrm{SiO}_{2}$ (2) indicating these diamonds are dominantly peridotitic and are derived from the transition zone and lower mantle (ca. $400 \mathrm{~km}$ to $670 \mathrm{~km}$ ). This is the first report of CaSiperovskite in a LDG diamond.

Ferropericlase occurs together with $\mathrm{MgSiO}_{3}+(\mathrm{Fe}$, $\mathrm{Mg})_{2} \mathrm{SiO}_{4}, \mathrm{CaSiO}_{3}+\mathrm{MgSiO}_{3}$ and $\mathrm{SiO}_{2}$. $\mathrm{Mg} \#$ ranges between 83.4 and 89.6 (av. 85.7) and $\mathrm{Ni}$ and $\mathrm{Cr}$ contents are variable $\left(\leq 1.6 \mathrm{wt} \% \mathrm{NiO} ; \leq 2.6 \mathrm{wt} \% \mathrm{Cr}_{2} \mathrm{O}_{3}\right)$. The association of silicate phases with ferropericlase indicates that these diamonds are lower mantle in origin and did not form in lower pressure conditions of low silica activity (eg. Stachel et al., 2000).

The $(\mathrm{Mg}, \mathrm{Fe})_{2} \mathrm{SiO}_{4}$ inclusion occurring in a $\mathrm{DO} 27$ microdiamond has a high $\mathrm{Mg \#} \mathrm{(96.5)} \mathrm{and} \mathrm{low} \mathrm{Ni}(0.08$ $\mathrm{wt} \% \mathrm{NiO})$ compared to olivine inclusions in diamond. The coexistence of $(\mathrm{Mg}, \mathrm{Fe})_{2} \mathrm{SiO}_{4}$ with fPer and $\mathrm{MgPvk}$ constrains the formation of this diamond to a narrow stability window at $\sim 22 \mathrm{GPa}$ corresponding to the $670 \mathrm{~km}$ seismic boundary layer (e.g. Ito and Takahashi, 1989).

\section{DIAMOND FORM AND NITROGEN CHARACTERISTICS}

The eclogitic diamonds divide into two groups based on morphology and nitrogen characteristics analysed by FTIR spectra. More than half of the diamonds have cubooctahedral forms and low nitrogen aggregation states (Type IaA) without the development of platelets. These features suggest the diamonds are young and may have crystallised close to the time of kimberlite emplacement.

The other group comprises diamonds with octahedral morphologies that are either $\mathrm{N}$-free (Type II) or have higher aggregation states (Type IaA-IaB) suggesting an older group of diamonds. Nitrogen contents average about $550 \mathrm{ppm}$ in DO27 diamonds and 400 in other LDG Type I diamonds.

Peridotitic diamonds, all of octahedral form, comprise equal numbers of Type II and Type IaA-IaB nitrogen aggregation states suggesting a possible longer mantle residence than eclogitic diamonds. Nitrogen contents average $540 \mathrm{ppm}$ for DO27 and $380 \mathrm{ppm}$ for other LDG diamonds. Ultradeep diamonds are resorbed octahedra and are predominantly nitrogen-free.

\section{CARBON ISOTOPES}

Carbon isotopes analysed from 105 of 247 LDG microdiamonds have values ranging from $\delta^{13} \mathrm{C}=-16.8 \%$ to $-2.1 \%$ PDB, skewed from a peak at $-4.7 \%$ to more ${ }^{13} \mathrm{C}$ depleted values (Fig. 1a). Microdiamonds from individual kimberlites, with the exception of DO27, show a similar isotopic range and distribution to the group as a whole. The carbon isotopic range of eighty DO27 microdiamonds is greater but has a similar mode to other LDG diamonds in this study $\left(\delta^{13} \mathrm{C}=-35.8\right.$ to $+0.2 \%$; mode $=-5.2 \%$; Fig. 1 b).

The $\delta^{13} \mathrm{C}$ mode of eclogitic LDG is $-7.4 \%$ o $\left(\delta^{13} \mathrm{C}\right.$ range $=-$ $15.0 \%$ to $-2.2 \%$ ), a peak that is not observed in the DO27 diamonds. The LDG peridotitic and ultradeep diamonds have similar $\delta^{13} \mathrm{C}$ modes to $\mathrm{DO} 27(\mathrm{P}=\sim 5.2 \%$; range $=-11.5$ to -2.3 ; $\mathrm{UD}=\sim 4.6 \%$; range $=-8.8$ to $2.1 \%$ ).

The $\delta^{13} \mathrm{C}$ range of DO27 eclogitic diamonds is -35.8 to $3.6 \%$, with peaks at $-5,-12$ and $-19 \%$. The range for peridotitic diamonds is $-18.7 \%$ o to $+0.2 \%$ (mode $=-$ $4.2 \%$ ). The $\delta^{13} \mathrm{C}$ range for $\mathrm{DO} 27$ ultradeep diamonds is $14.3 \%$ to $-2.5 \%$ (mode $=-4.2 \%$ ). Carbon isotope analyses of 53 DO27 macrodiamonds yielded a similar distribution of values (Davies et al., 1999). 


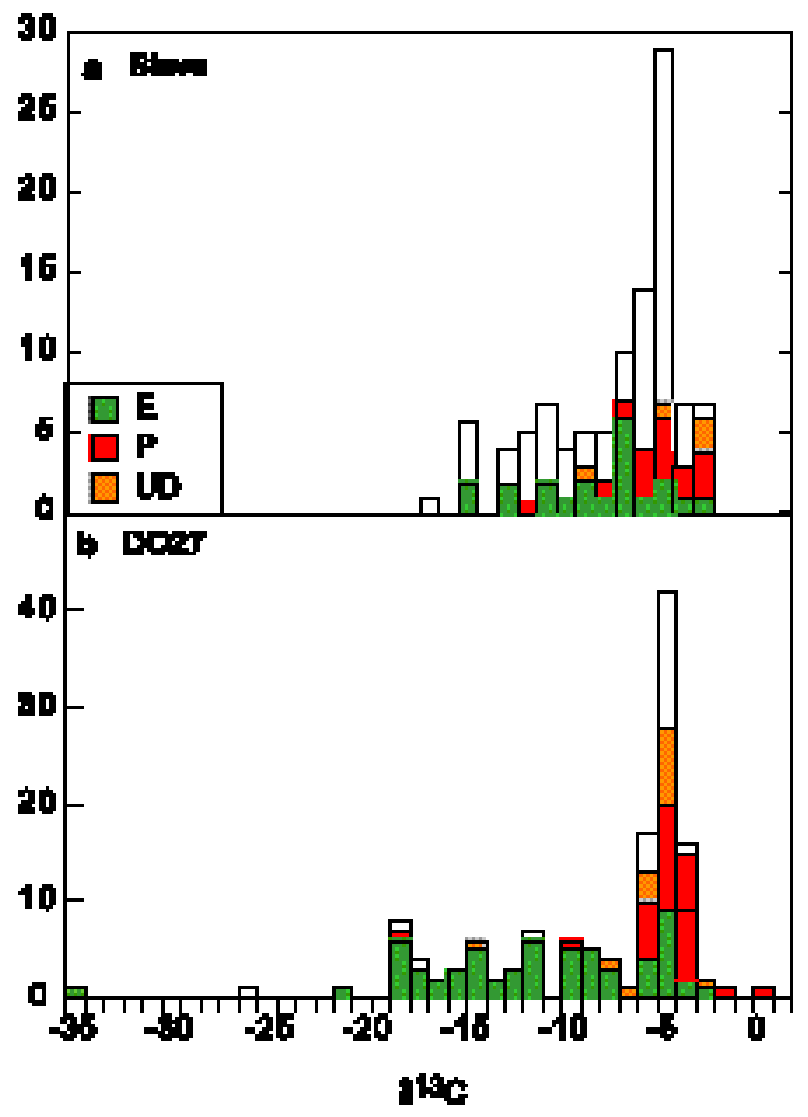

Figure 1. Carbon isotope compositions of the LDG (a) and DO27 (b) microdiamonds with fields defined for eclogitic, peridotitic and ultradeep paragenetic groups.

\section{DISCUSSION}

Eclogitic diamonds from the DO27 and LDG kimberlites show evidence of growth in the mantle over a significant time from their cubo-octahedral and octahedral forms coupled with variable nitrogen aggregation characteristics. However mineral inclusion data do not delineate variations between subgroups suggesting the mantle composition was constant over that time. A bulk composition calculated from eclogitic garnet and clinopyroxene inclusions has an NMORB trace-element signature, and ${ }^{13} \mathrm{C}$-depleted carbon (bimodal peaks at $\delta^{13} \mathrm{C}=-5 \%$ and $-19 \%$; $\min =-35.8 \%$ ) supports an origin from subducted oceanic crust.

$\mathrm{T}_{\mathrm{Ni}}$ data from harzburgitic and lherzolitic garnet inclusions in the DO27 and Slave diamonds suggest the diamonds are derived from both the upper ultra-depleted harzburgitic layer and the deeper less depleted lherzolitic layer of the stratified central Slave Craton sub-cratonic lithosphere (Griffin et al., 1999). Mineral inclusion data, primordial average carbon isotope compositions $\left(\delta^{13} \mathrm{C}\right.$ ca. $-4.5 \%$ ), octahedral shapes and moderate nitrogen aggregation states suggest an ancient sub-cratonic lithospheric origin for these diamonds. Ultradeep diamonds with fertile peridotitic inclusion compositions also have carbon isotope compositions suggesting their derivation from a primoridial carbon source in the uppermost lower mantle.

Peridotitic Slave and DO27 microdiamonds in this study, and DO27 macrodiamonds (Davies et al., 1999) are indistinguishable with regard to morphological, IR and carbon isotopic characteristics. The DO27 eclogitic microdiamonds have similar mineral inclusion chemistries, carbon isotopes and nitrogen contents to the DO27 macrodiamonds. The predominance of eclogitic cubo-octahedral forms with low nitrogen aggregation states in the microdiamond group was not observed in the macrodiamond study. This indicates differences in the mechanisms and timing of growth of some micro- and macrodiamond populations.

This diamond inclusion study supports other studies in the area that identify plume tectonics as being a key component in the formation of the Central Slave Craton (Griffin et al., 1999). In this model, the ultradeep diamonds were transported to the base of the Slave Craton in a plume, where they were later sampled by a kimberlite and emplaced at the earth's surface. The abundance of eclogitic diamonds in the kimberlites sampled in this study appears to be intrinsic to this process.

This suggests a relationship between diamond formation and the accumulation of basaltic material in the cratonic upper mantle in regions of plume activity. The link between these observations may be the subduction and accumulation of oceanic crust at the upper-lower mantle boundary (e.g. megalith model of Ringwood, 1994) followed by entrainment in a plume and subcretion onto the base of a cratonic keel.

\section{REFERENCES}

Davies, RM, Griffin, WL and O'reilly, SY (1999): Diamonds from the deep: pipe DO27, Slave craton, Canada; Proc Seventh International Kimberlite Conf., Cape Town, South Africa, pp. 148-155.

Ellis, DJ and Green, DH (1979): An experimental study of the effect of $\mathrm{Ca}$ upon garnet-clinopyroxene $\mathrm{Fe}-\mathrm{Mg}$ exchange equilibria; Contributions to Mineralogy and Petrology, 71: $13-22$.

Griffin, WL, Doyle, BJ, Ryan, CG, Pearson, NJ, O'Reilly, SY, Davies, RM, Kivi, K, Van Achterbergh, E and Natapov, LM (1999): Layered mantle lithosphere in the Lac de Gras area, Slave Craton: composition, structure and origin; Journal of Petrology, 40: 705-727.

Griffin, WL, Ryan, CG, Gurney, JJ, Sobolev, NV and Win, TT (1991): Chromite macrocrysts in kimberlites and lamproites: geochemistry and origin; In HOA Meyer and $\mathrm{OH}$ Leonardos, eds, Kimberlites and Related Rocks and 
Mantle Xenoliths, CPRM Spec Publ 1A/93, pp. 366-377.

Harlow, GE and Veblen, DR (1991): Potassium in clinopyroxene inclusions from diamond; Science, 251: 652-655.

Harte, B, Harris, JW, Hutchison, MT, Watt, GR and Wilding, MC (1999): Lower mantle mineral associations in diamonds from Sao Luiz, Brazil; In Y Fei, CM Bertka and BO Mysen, eds., Mantle Petrology: Field Observations and High Pressure Experimentation: A tribute to Francis R (Joe) Boyd, The Geochem. Soc. Spec. Publ. 6, 125-153.

Irifune, T (1987): An experimental investigation of the pyroxenegarnet transformation in a pyrolite composition and its bearing on the constitution of the mantle; Earth and Planetary Science Letters, 45: 324-336.

Ito, $\mathrm{E}$ and Takahashi, E (1989): Postspinel transformations in the system $\mathrm{Mg}_{2} \mathrm{SiO}_{4}-\mathrm{Fe}_{2} \mathrm{SiO}_{4}$ and some geophysical implications; Journal of Geophysical Research, 94: 1063710646.

Kaminsky, FV, Zakharchenko, OD, Davies, RM, Griffin, WL, Khachatryan-Blinova, GK and Shiryaev, AA (2000): Superdeep diamonds from the Juina Area, Mato Grosso
State, Brazil; Contributions to Mineralogy and Petrology, 140: 734-753.

Meyer, HOA (1987): Inclusions in diamond; In PH Nixon, ed., Mantle Xenoltihs, John Wiley and Sons, pp. 501-522.

Ringwood, AE (1994): Role of the transition zone and $660 \mathrm{~km}$ discontinuity in mantle dynamics; Phys Earth Planet Inter, 86: 5-24.

Ryan, CG, Griffin, WL and Pearson, NJ (1996): Garnet geotherms: a technique for derivation of P-T data from $\mathrm{Cr}$ Pyrope garnets; Journal of Geophysical Research, 101: 5611-5625.

Stachel, T, Harris, JW, Brey, GP and Joswig, W (2000): Kankan dimonds (Guinea) II: lower mantle inclusion paragenesis; Contributions to Mineralogy and Petrology, 140: 16-27.

Contact: RM Davies, Department of Earth and Planetary Sciences, American Museum of Natural History, Central Park West at $79^{\text {th }}$ St, New York, NY 10024-5192, USA. Email: rdavies@amnh.org; Tel: 1-212-769 5314; Fax: 1-212-769 5339 